\title{
山地平原过渡带地形起伏特征及其对景观格局的 影响——太行山淇河流域为例
}

\author{
张静静, 朱文博, 赵芳, 朱连奇", 李茂娟, 朱明, 张晓东
}

河南大学环境与规划学院, 开封 475004

* 通讯作者, E-mail: 1qzhu@henu.edu.cn

收稿日期：2017-03-27; 收修改稿日期：2017-11-28; 接受日期：2017-12-01; 网络版发表日期：2018-01-29

国家重点基础研究发展计划项目(编号: 2015CB452702)和国家自然科学基金项目(批准号: 41671090和41601091)资助

摘要 地形对过渡带景观格局的形成起关键作用, 定量探讨其作用机理有助于科学解释复杂地域单元的景观格 局, 从而深入理解其演变过程. 文章以位于山地平原过渡带的太行山淇河流域为例, 采用均值变点法提取地形起 优度, 从类型和景观两个尺度探讨地形起优度对景观格局的影响, 并利用Logistic回归模型研究不同地形起优度 区自然和人为因素与景观格局的定量关系，从而阐释其影响机理。结果表明：(1) 淇河流域地形以小起优 (70 200m) 为主, 主要位于淇河中上游; 其次为平坦 $(0 \sim 30 \mathrm{~m})$ 及微起优 $(30 \sim 70 \mathrm{~m})$, 位于研究区两端及中部林州境内; 中起伏 $(\geq 200 \mathrm{~m})$ 占比例较少, 位于河南与山西及林州与鹤壁的交界处. (2) 随地形起优度增加, 景观类型由人为景 观逐渐向自然景观过渡, 景观多样性和破碎度先增后减, 蔓延度和聚集度先减后增. (3) 随地形起伏度增加, 对景 观类型分布具有解释作用的因素逐渐由人为因素占主导转为以自然因素占主导. 同时, 人为干扰的综合影响逐渐 减弱，在平坦区人为干扰使林地和草地分布概率比自然状态下分别减少 $41.26 \%$ 和 $7.74 \%$, 而在中起伏区两者的分 布概率仅减少 $1.36 \%$ 和 $0.22 \%$. 由此可见, 山地平原过渡带显著的地形起优特征带来的水热与人为活动的差异是景 观格局形成的直接原因.

关键词山地平原过渡带, 地形起优度, 均值变点法, 景观格局, Logistic回归分析, 影响机理

\section{1 引言}

山地平原过渡带是山地与平原两大地域单元的交 接地带, 具有明显的自然地理边缘效应, 形成高度异质 的景观特征；同时显著的地形起伏特征通过对景观格 局的自然选择作用以及对人类活动的限制作用，使景 观格局呈现明显的空间分异规律(管华，2006; 哈凯等,
2015). 因此，地形是山地平原过渡带景观格局空间分 异的主导控制因子，通过立地条件影响陆地生态系统 物质与能量的再分配，并通过干扰发生频率及强度来 影响景观格局(Pe'er等, 2006; Zhang和Yao, 2016). 近 年来地形因子与景观格局的关系已成为自然地理学与 生态学研究的重要内容之一(Odgaard等, 2014; Hais等, 2016; Walz等, 2016), 科学探讨地形分异对景观格局的

\footnotetext{
中文引用格式: 张静静, 朱文博, 赵芳, 朱连奇, 李茂娟, 朱明, 张晓东. 2018. 山地平原过渡带地形起伏特征及其对景观格局的影响一以太行山淇河流域为 例. 中国科学: 地球科学, 48: 476-486, doi: 10.1360/N072016-00417

英文引用格式: Zhang J J, Zhu W B, Zhao F, Zhu L Q, Li M J, Zhu M, Zhang X D. 2018. Spatial variations of terrain and their impacts on landscape patterns in the transition zone from mountains to plains-A case study of Qihe River Basin in the Taihang Mountains. Science China Earth Sciences, 61: 450-461, https://doi.org/10.1007/s11430-016-9158-2
} 
影响，有助于深入了解景观格局的空间分异规律以及 为景观格局空间优化奠定基础.

地形为景观格局的形成提供物理模板，同时还制 约着景观的演变过程. 已有研究宏观地分析了地形在 景观格局研究中的重要性, 指出在森林生态系统研究 和管理中以及在评估农业景观中自然植被变化的人为 影响时要充分考虑地形的制约作用(Dorner等，2002; Lippok和Schleuning, 2013; Pekin, 2016); 通过将三维 地形结构整合到景观格局的研究中, 发展了一种适用 于地形复杂区的三维景观指数 (Hoechstetter等, 2008; Walz等，2016). 同时借助GIS空间分析和典范对应分 析(CCA)等方法，探究了不同尺度地形对景观格局的 影响(赵卫权等, 2010; 张春英和张春玲, 2012; 哈凯等, 2015), 并分析了地形对景观格局演变过程的影响(国 巧真等，2015). 研究发现景观格局的空间分布存在明 显的地形梯度特征, 随地形级别的增加, 人工生态系统 逐渐向自然生态系统过渡, 而景观格局演变的速度逐 渐减缓. 但已有研究仅限于两者关系的表象分析，缺 乏其作用机理的定量探讨，尤其针对山地平原过渡带 小流域尺度的研究更是少见. 流域已成为研究陆地表 层系统科学的绝佳单元，是“水-土-气-生-人”集成研究 的基地(程国栋和李新, 2015), 选择地貌类型齐全的小 流域作为案例, 定量探讨地形对景观格局的影响机理, 从而更深刻地认识格局对过程的制约作用，同时对于 构建一个可代表区域景观格局形成机理的空间异质性 的网络, 具有重要的意义.

显著的地形起伏是山地平原过渡带的主要地形特
征, 对景观格局的形成和变化起关键作用(管华, 2006). 地形起伏度是表征地形起伏特征的定量指标, 能直观 反映地形地貌特征(范建容等, 2015); 但地形起伏度的 计算具有不确定性及计算尺度的依赖性, 科学界定其 计算尺度(即最佳统计单元)是确定区域地形起伏度的 关键(Prima等, 2006). 根据已有研究, 非人工判别法中 的“均值变点分析法”能够快速、准确地确定最佳统计 单元，得到了广泛应用(范建容等, 2015; Yu等, 2015). 本文选择位于太行山南段向华北平原过渡地带的淇河 流域开展研究, 利用该方法提取地形起伏度, 从类型和 景观两个尺度探讨地形起伏度与景观格局的关系, 并 采用Logistic 回归模型研究不同地形起伏度区自然和 人为活动与景观格局的定量关系, 阐释其影响机理. 研 究有助于甄别复杂地域单元景观格局形成的主控因 素, 准确识别人为干扰的相对作用, 构建能有效调节生 态过程的景观格局分布模式，同时为不同地貌单元人 类活动强度的调整提供理论基础.

\section{2 研究区概况}

淇河流域地处太行山南段东麓, 介于 $113^{\circ} 17^{\prime} \sim 114^{\circ}$ $23^{\prime} \mathrm{E}$ 和 $35^{\circ} 32^{\prime} \sim 36^{\circ} 04^{\prime} \mathrm{N}$ 之间, 位于中国地形第二阶梯的 东缘，东与华北平原相接(图1). 淇河是海河水系卫河 的支流，发源于山西陵川，流经山西壶关以及河南的 辉县、林州、鹤壁、淇县和浚县, 于浚县刘庄和共产 主义渠相汇并最终流入卫河; 全长约 $165 \mathrm{~km}$, 流域面积 $2227 \mathrm{~km}^{2}$. 海拔自西向东递减, 高差起伏较大. 河流、谷

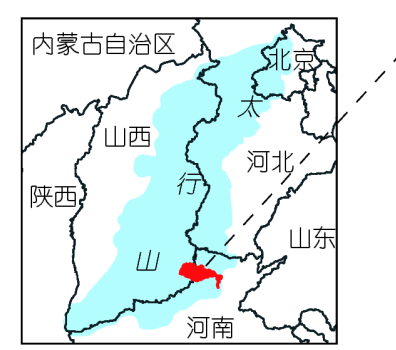

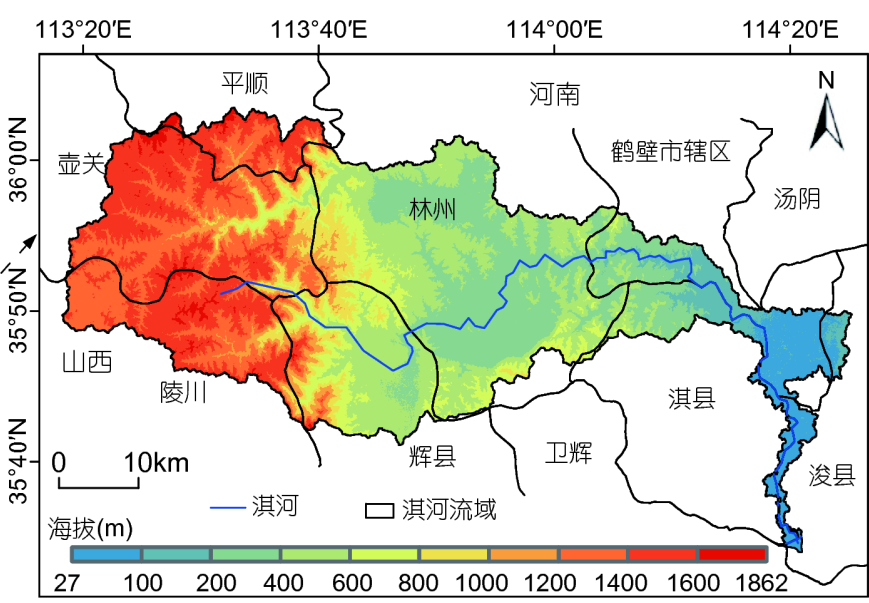

图 1 研究区位置及高程示意图 
地横穿研究区, 地貌类型有盆地、平原、丘陵及山地, $86 \%$ 的区域为丘陵和山地. 年均气温 $11.9^{\circ} \mathrm{C}$, 年均降水 量 $573.7 \mathrm{~mm}$, 属暖温带半湿润季风气候. 该区植被垂直 分异明显, 根据太行山南段植被垂直带谱的记录(广生 舜，1991; 茹文明，1993)，自下而上依次出现低山灌从 及农作物带、低中山落叶阔叶林带、中山针阔叶混交 林带、山顶灌从草甸带.

\section{3 数据与研究方法}

\section{1 基础数据}

DEM数据来源于ASTER GDEM, 经拼接、投影、 裁剪得到研究区DEM. 土地利用数据是基于 2015 年的 Landsat 8遥感影像(来源于地理空间数据云, http:// www.gscloud.cn/)，参考2005年该区1:10万土地利用类 型图(来源于黄河下游科学数据中心, http://www.geodata.cn/), 进行人工目视解译，根据中国土地资源分类 系统(刘纪远, 1997), 得到2015年土地利用二级类型图, 并进行实地调研验证, 解译精度达到 $86 \%$. 然后在ArcGIS中将二级类合并为一级类, 并赋予一级类型图中 的斑块新的属性, 即景观类型, 分为耕地、林地、草 地、水域、建设用地和未利用地六类, 并由矢量转为 栅格格式, 以在Fragstats中进行景观指数的计算.

本文所选自然和人为因子分别为受地形起伏影响 较大的水热及人为干扰因子. 水热因子主要为气温和 降水，由山西省和河南省气象局提供，共10个气象站 点的2015年年均气温和年降水量，并利用ANUSPLIN 插值软件, 以经纬度为自变量, 海拔高度为协变量, 分 别进行插值得到栅格数据. 人为干扰因子选取人口密 度和距离因素，人口密度来源于 2016 年《山西省统计 年鉴》和《河南省统计年鉴》，并进行空间栅格化. 距离因素是借助欧氏距离法对农村居民点和道路数据 计算得到，农村居民点是由上述土地利用二级类型图 提取得到, 道路数据来源于黄河下游科学数据中心. 本文的栅格数据统一使用Grid格式，空间分辨率为 30m, 地理坐标系采用WGS 1984 Albers.

\section{2 研究方法}

本文首先利用均值变点法提取地形起伏度，然后 分别从类型和景观两个尺度探讨地形起伏度对景观格 局的影响. 按地形指数划分流域并分别模拟不同地形
特征下的逐日水量平衡, 能提高模拟精度(邓慧平和孙 菽芬，2012). 而不同地形特征下景观格局形成的主控 因素有很大的差别，因此本文按照地形起伏度划分流 域, 即对地形起伏度进行分级, 并利用Logistic模型分 析不同地形起伏度区景观格局与驱动因子之间的关 系, 从而揭示其影响机理. 本文的技术路线如图2所示.

\subsection{1 地形起伏度的提取}

地形起伏度的计算具有尺度依赖性. 本文首先采 用移动窗口法计算不同尺度的地形起伏度，对DEM依 次开辟 $n \times n(n=2,3, \ldots, 30)$ 像元大小的窗口, 计算各窗 口下每个栅格邻域海拔的最大值和最小值之差，即不 同窗口下的地形起伏度，其平均值随窗口大小的变化 呈对数曲线特征(图3a), 拟合度为 0.97 . 可见, 在 $8 \sim 15$ 万 $\mathrm{m}^{2}$ 曲线上出现由陡变缓的点, 称为变点. 变点对应 的窗口大小即为最佳统计单元.

然后采用均值变点法确定变点, 该方法是基于数 理统计的一种分析方法, 可用来计算一列数据中出现 异常、发生突变的点, 对恰有一个变点的计算最有效 (范建容等, 2015). 步骤如下:

(1) 将不同窗口下地形起伏度平均值与对应窗口 面积依次相除, 得到各窗口下单位面积起伏度 $T_{t}$, 对其 取对数, 得到数列 $\left\{X_{t}\right\}$, 见式(1), 并计算出数列方差 $S$ 为 18.66 .

$$
X_{t}=\ln T_{t},
$$

式中, $t$ 为窗口个数, 取值 $1,2,3, \ldots, 29$.

(2) 令 $i=2,3, \ldots, 29$, 每一个 $i$ 值将数列分成两部分, 即 $\left\{X_{1}, X_{2}, \ldots, X_{i-1}\right\}$ 和 $\left\{X_{i}, X_{i+1}, \ldots, X_{29}\right\}$, 然后分别求每 部分的算术平均值 $X_{i 1} 、 X_{i 2}$ 和统计量 $S_{i}$ :

$$
S_{i}=\sum_{t=1}^{i-1}\left(X_{t}-X_{i 1}\right)^{2}+\sum_{i=i}^{29}\left(X_{t}-X_{i 2}\right)^{2} .
$$

(3) 求取 $S$ 与 $S_{i}$ 的差值, 差值达到最大时对应的窗口 面积即为最佳统计单元的大小.

图3b显示了 $S$ 与 $S_{i}$ 差值数据序列的变化曲线, 在第 10 个点(即 $i=11$ )差值达到最大(13.61), 该点对应的窗口 为 $12 \times 12$ 像元. 由此得出, 利用 $30 \mathrm{~m}$ 分辨率的 $\mathrm{DEM}$ 数据 计算淇河流域地形起伏度的最佳统计单元大小为 $0.13 \mathrm{~km}^{2}$. 基于此, 得到淇河流域地形起伏度为 $0 \sim 503 \mathrm{~m}$, 平均为 $105.7 \mathrm{~m}$. 


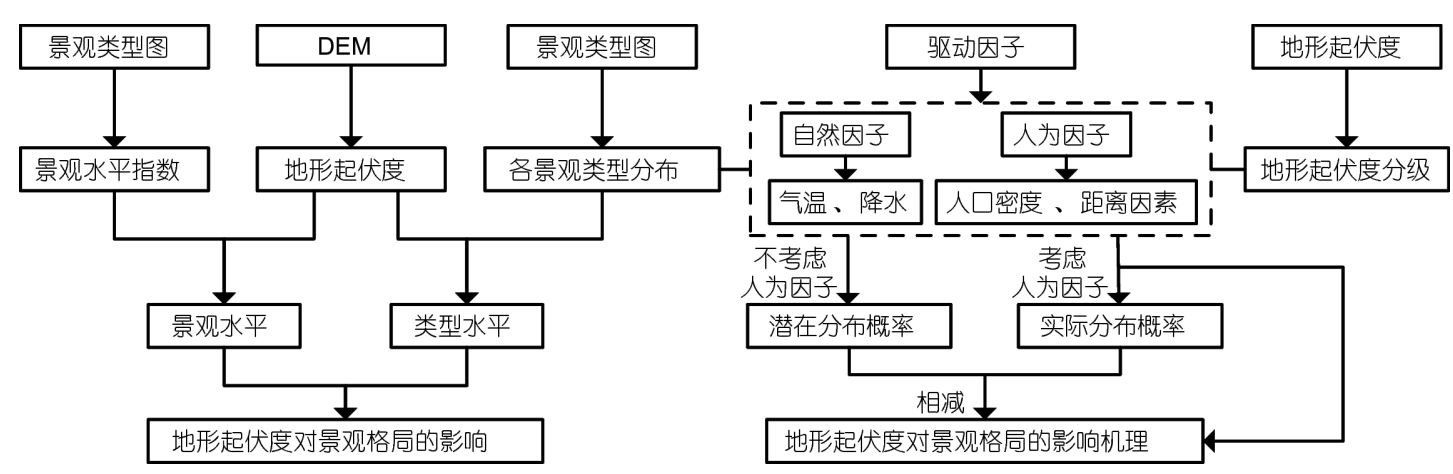

图 2 技术路线
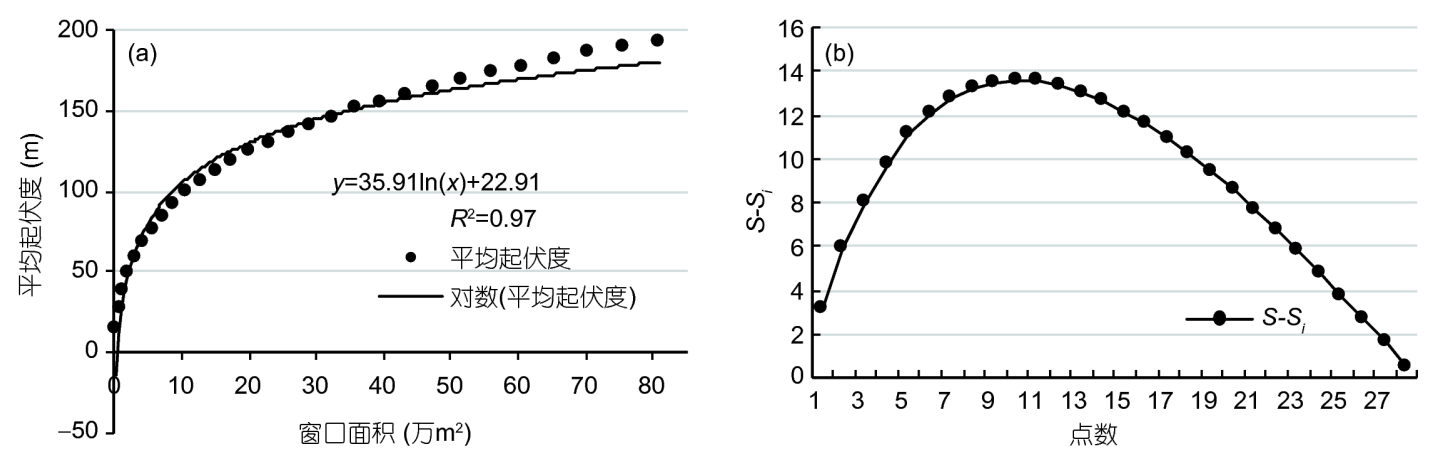

图 3 地形起伏度平均值与窗口大小的关系(a)以及 $S$ 与 $S_{i}$ 差值的变化曲线(b)

\subsection{2 景观格局指数的计算}

景观格局指数高度浓缩了景观格局的信息，能够 定量表征景观的结构组成及其空间配置特征(乌建国, 2007). 为全面反映研究区景观格局破碎度和多样性的 空间分异特征，以定量比较不同地形特征上自然和人 为因素对景观格局综合影响的差异，本文选取景观水 平上斑块密度 $(\mathrm{PD})$ 、景观形状指数 (LSI)、蔓延度 (CONTAG)和聚集度 $(\mathrm{AI})$ 反映景观破碎度, 选取Shannon多样性指数(SHDI) 和Shannon均匀度指数(SHEI) 反 映景观多样性. 然后采用Fragstats中的移动窗口法, 通 过筛选选择边长为 $2800 \mathrm{~m}$ 的矩形窗口进行计算; 由于 计算结果返回中心栅格, 因此先对研究区做宽度为 $1400 \mathrm{~m}$ 的缓冲区再进行计算，从而得到研究区完整的 景观指数空间分布，同时消除了边界效应的影响。以 上指数的计算公式及生态学意义详见文献 $(\mathrm{Li}$ 和 $\mathrm{Wu}$, 2004; 邬建国, 2007).

\subsection{3 景观格局形成机理的分析}

当因变量是二分类变量时, 常采用Binary Logistic 回归模型进行分析. 已有学者利用该模型定量分析区
域土地利用格局变化的驱动因素(荣子容等, 2012; Achmad等, 2015). 并采用Pontius和Schneider(2001)提 出的ROC曲线(Relative Operating Characteristics)对模 拟结果进行检验，当ROC值大于 0.7 时，表示所选驱动 因素具有较好的解释能力. 本研究运用该模型定量分 析不同地形起伏度区景观格局与驱动因子的关系, 从 而揭示景观格局的形成机理.

为了更准确地识别人为干扰因子对林地和草地的 综合作用在不同地形起伏度区的差异, 首先根据Logistic 回归系数, 在ArcGIS栅格计算器中计算林地和草 地的实际分布概率, 然后计算不考虑人为因子情况下 的分布概率, 即潜在分布概率; 进而采用两者差值衡 量不同地形起伏度区人为干扰的综合影响, 差值大于 0 , 表明人为干扰对景观分布有正向影响, 差值小于 0 , 表明人为干扰对景观分布有负向影响.

\section{4 结果分析}

\section{1 淇河流域地形起伏度空间分异特征}

由图4a发现，淇河流域地形起伏度分布比例分别 

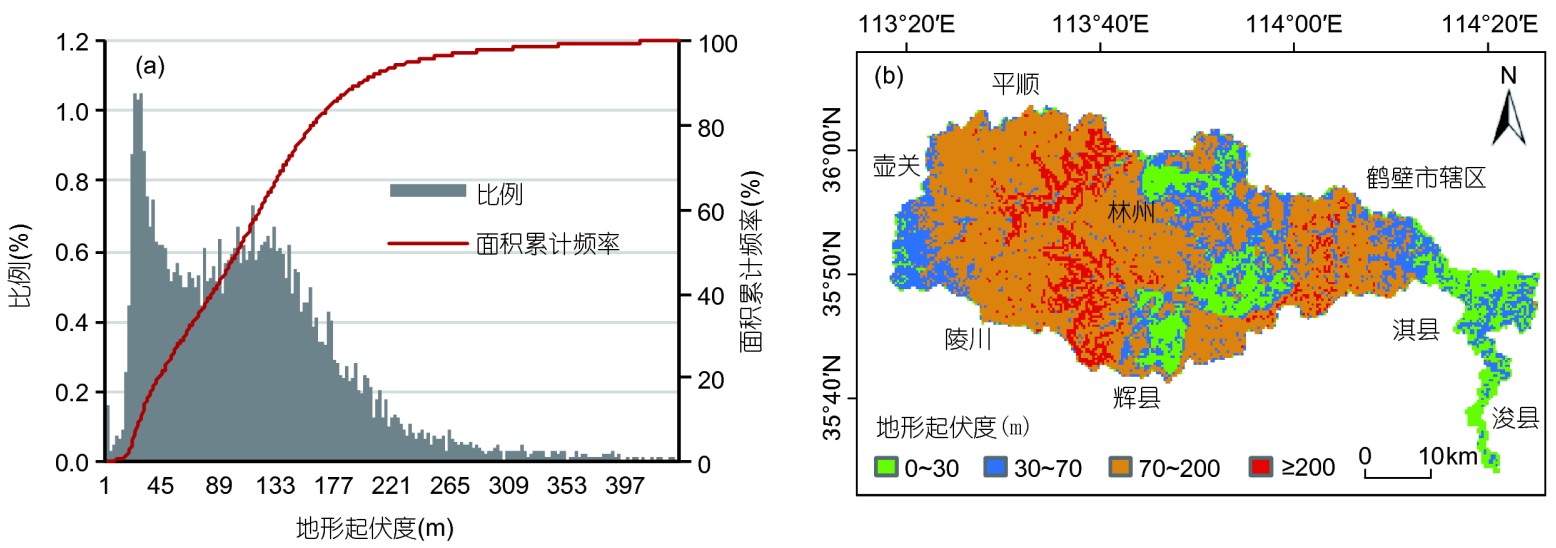

图 4 淇河流域地形起伏度分布比例与累计频率及其空间分布图

在 $30 \mathrm{~m}$ 和 $122 \mathrm{~m}$ 附近出现峰值; 在地形起伏度为 $200 \mathrm{~m}$ 时，累计频率已达到 $91.68 \%$ ，表明地形起伏度以中低 值为主.

参考中国数字地貌制图规范中的分级标准(周成 虎等, 2009), 并结合研究区复杂多样的地形特征, 将地 形起伏度划分为 4 个等级(表1; 图4b). 可见，淇河流域 地形以小起伏为主 $(56.29 \%)$, 主要位于淇河中上游, 分 别以中起伏区为中心向东西两侧展开; 其次是微起伏 (21.08\%), 主要分散分布在淇河中下游, 部分集中分布 在最西端的陵川与壶关境内; 平坦区占 $14.31 \%$ ，位于 林州境内及下游区域; 中起伏占 $8.32 \%$, 约 $185 \mathrm{~km}^{2}$, 主 要位于河南与山西交界处，小部分位于林州与鹤壁交 界处.

\section{2 地形起伏度对景观格局的影响}

\subsection{1 地形起伏度对景观类型空间分布的影响}

淇河流域景观类型以草地、林地和耕地为主，其 次为建设用地、水域和未利用地(图5a), 并统计景观 类型在不同地形起伏度上的分布(图5b). 可见，随地形 起伏度增加, 各类型所占比例的变化可分为三种类型: 持续减少型,包括耕地、建设用地和水域; 先增加后减 少型, 包括草地和未利用地; 持续增加型, 只有林地. 平 坦区优势景观为耕地, 其次为建设用地, 两者占 $92.5 \%$, 该区为人类活动的热点地区，是人地矛盾最激烈的区 域，如何进行合理的资源配置以实现经济发展和粮食 安全的共赢，是该区亟待解决的问题. 在微起伏和小 起伏区，各景观类型均有分布，微起伏区优势景观为 耕地(56.58\%)，其次为草地(27.71\%)，小起伏区优势景
表 1 淇河流域地形起伏度统计结果

\begin{tabular}{cccc}
\hline 地形起伏度 $(\mathrm{m})$ & 像元数量 $($ 个) & 面积 $\left(\mathrm{km}^{2}\right)$ & 面积比例 $(\%)$ \\
\hline $0 \sim 30$ (平坦) & 354210 & 318.79 & 14.31 \\
$30 \sim 70$ (微起伏) & 521600 & 469.44 & 21.08 \\
$70 \sim 200$ (小起伏) & 1393108 & 1253.8 & 56.29 \\
$\geq 200$ (中起伏) & 205842 & 185.25 & 8.32 \\
合计 & 2474760 & 2227.28 & 100 \\
\hline
\end{tabular}

观为草地(42.61\%)和林地(40.39\%), 耕地占 $15.04 \%$. 该 区为自然景观和人为景观的交错分布带, 两者存在激 烈的竞争关系，边缘效应明显，表现为人为景观向自 然景观过渡, 应重点协调两者的关系, 土地结构优化 要坚持生态保护为主、资源开发为辅的原则. 在中起 伏区，优势景观为林地(66.6\%), 其次为草地 $(28.4 \%)$, 自然景观占绝对优势, 人类的开发利用活动受到限制, 因此应充分发挥其生态屏障的作用.

\subsection{2 地形起伏度对景观指数空间分布的影响}

为定量分析淇河流域地形起伏度与景观格局的关 系, 统计基于柱格的地形起伏度值与景观指数, 并进行 多项式拟合(图6). 可见, 随地形起伏度增加, 景观指数 的变化趋势可分为两种类型：先增加后减少型，包括 PD、LSI、SHDI、SHEI，拟合度分别为 $0.78 、 0.71$ 、 $0.67 、 0.57$; 先减少后增加型，包括CONTAG和AI，拟 合度分别为 0.50 和 $0.68 . P D 、 L S I 、 S H D I$ 和SHEI空间 分布具有相似性，PD和LSI大的区域，SHDI和SHEI也 较高, 高值区主要分布在地形起伏度适中的区域, 自然 景观和人为景观交错分布, 类型丰富, 破碎度高, 形状 

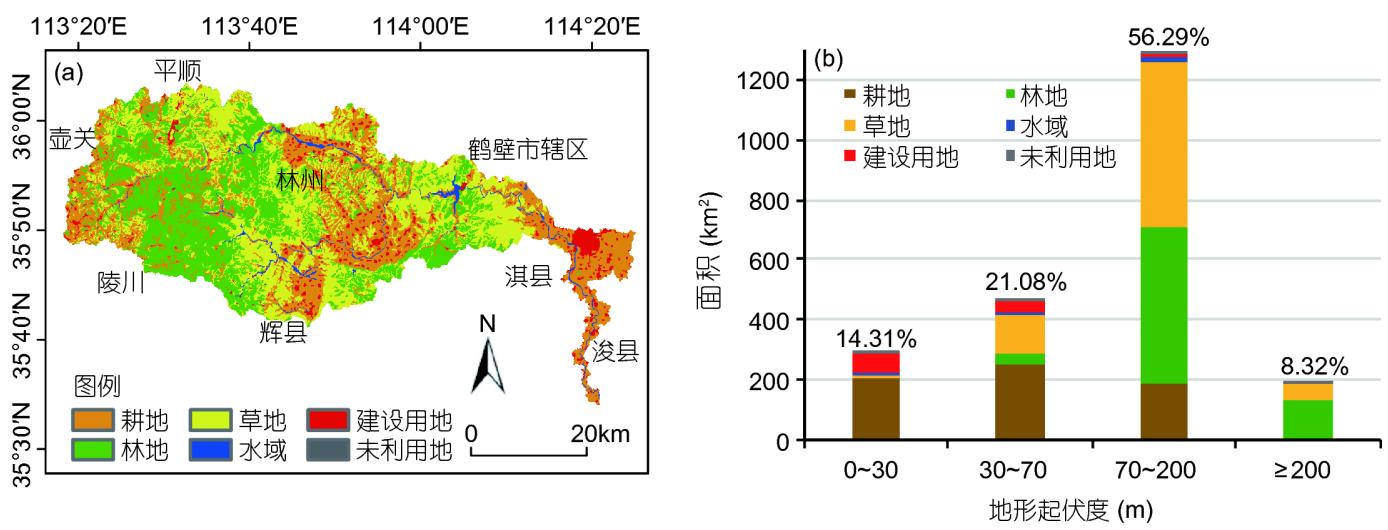

图 5 景观类型的空间分布及其随地形起伏度的变化
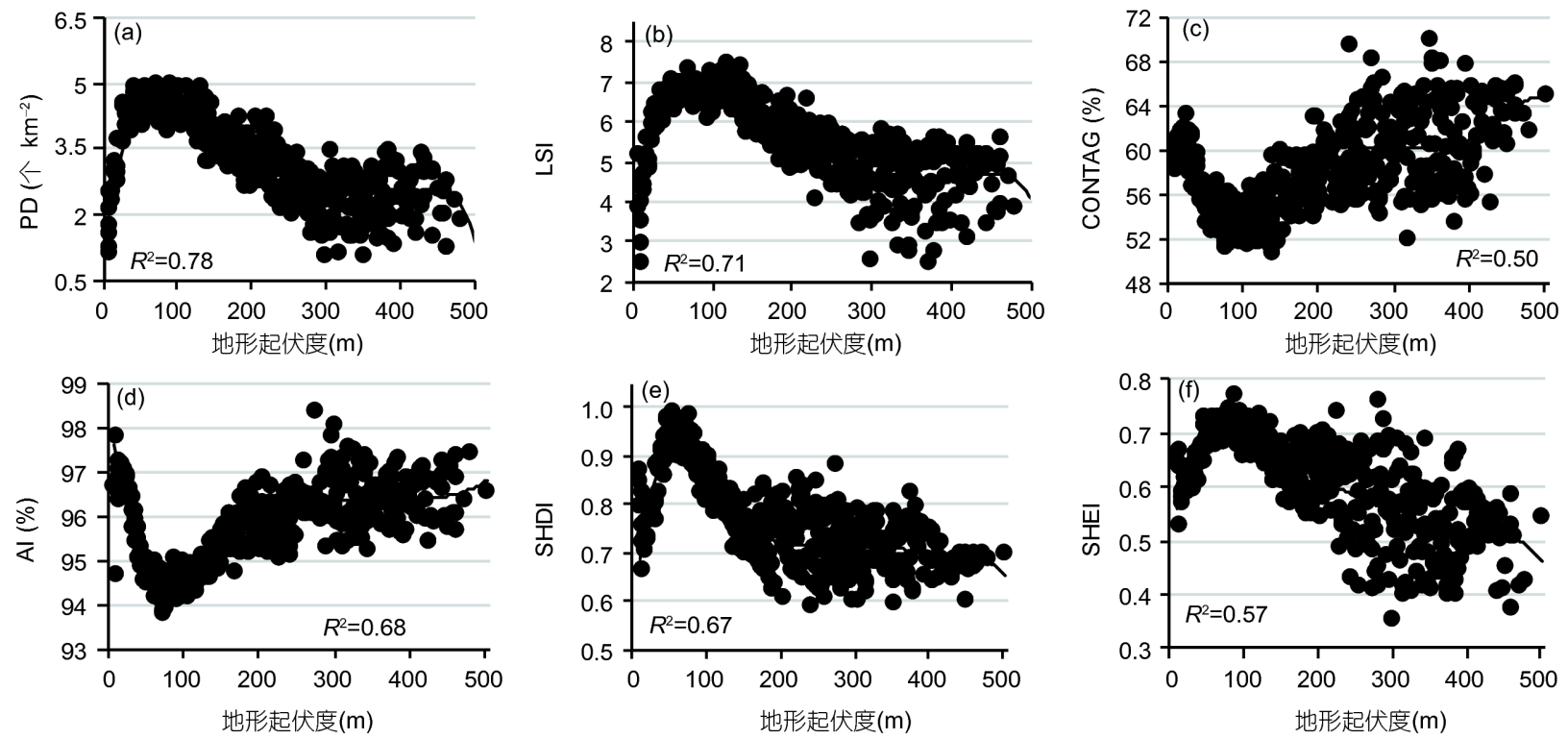

图 6 淇河流域不同景观指数与地形起伏度的关系

(a) 斑块密度(PD); (b) 景观形状指数(LSI); (c) 蔓延度(CONTAG); (d) 聚集度(AI); (e) Shannon多样性指数(SHDI); (f) Shannon均匀度指数(SHEI)

复杂, 多样性和均匀度也较高, 低值区主要分布在地形 起伏度偏小或偏大的区域，景观类型单一，呈连片分 布, 破碎度低, 多样性和均匀度也较低. CONTAG和AI 空间分布相似, 聚集度高的区域连通性较好, 蔓延度也 较高, 高值区和低值区的分布与上述四个指数表现出 相反的特征. 由此可见，地形起伏度是景观格局空间 分异的重要影响因素之一.

由表2发现, 平坦区CONTAG和AI达到最大, PD、 LSI、SHDI和SHEI相对较小, 该区自然景观连片分布, 斑块密度小, 形状规则, 多样性和均匀度较低, 蔓延度 和聚集度达到最大. 微起伏区PD、LSI、SHDI和SHEI
达到最大, CONTAG和AI较小, 该区景观类型丰富, 而 且分布相对均匀. 小起伏区优势景观类型有所减少, 与 微起伏区相比, PD、LSI、SHDI和SHEI略有减小, CONTAG和AI有所增加. 在中起伏区, 主要为自然景 观, 类型单一, 斑块面积大, 景观指数分布与平坦区类 似, 但形状相对更复杂. 由此可见, 微起伏区景观异质 性最强, 多样性和均匀度达到最大, 破碎化最严重, 连 通性和聚集度最差. 而小起伏区景观多样性略有降低, 但破碎化程度和连通性有所改善, 受干扰程度相对减 少，生物多样性水平高，应该是今后生态保护的关键 区. 但需要注重景观斑块的规划, 改善景观破碎化现 
表 2 不同地形起伏度上的景观指数

\begin{tabular}{ccccccc}
\hline 地形起伏度类别 & $\mathrm{PD}\left(\right.$ 个 $\left.\mathrm{km}^{-2}\right)$ & LSI & CONTAG $(\%)$ & AI $(\%)$ & SHDI & SHEI \\
\hline 平坦 & 3.07 & 4.39 & 60.51 & 96.78 & 0.77 & 0.61 \\
微起伏 & 4.51 & 6.14 & 55.02 & 95.01 & 0.91 & 0.68 \\
小起伏 & 3.99 & 5.88 & 55.08 & 95.05 & 0.80 & 0.67 \\
中起伏 & 2.55 & 4.41 & 60.32 & 96.28 & 0.71 & 0.55 \\
\hline
\end{tabular}

状, 维持该区生物多样性和稳定性.

\section{3 地形起伏度对景观格局的影响机理}

表3统计了不同地形起伏度区景观格局与驱动因 素之间的Logistic回归结果，ROC值均在 0.7 以，表明 所选驱动因子对景观格局的形成具有较强的解释能 力. 在中起伏区耕地、建设用地和水域以及小起伏区 建设用地和水域分布极少, 所以没有进行模拟.

耕地在平坦区主要受人为因素影响, 人口密度增 加 1 人 $\mathrm{km}^{-2}$, 耕地分布概率减少 $0.07 \%$, 距居民点及道 路距离分别增加 $1 \mathrm{~m}$ ，分布概率减少 $0.01 \%$ 和 $0.02 \%$; 在 微起伏区受自然和人为因素的共同影响，降水量增加 $1 \mathrm{~mm}$ ，分布概率减少 $0.25 \%$ ，而与人口密度变为正相 关，增加 1 人 $\mathrm{km}^{-2}$, 分布概率增加 $0.04 \%$; 在小起伏区 主要受自然因素影响，气温增加 $1{ }^{\circ} \mathrm{C}$, 分布概率减少 $8.30 \%$, 降水量增加 $1 \mathrm{~mm}$, 分布概率增加 $0.13 \%$, 在偏远 山区由于地形限制造成了只能靠天吃饭的种植模式.

林地和草地在平坦区主要受人为因素影响，人口 密度增加 1 人 $\mathrm{km}^{-2}$, 两者分布概率分别减少 $0.83 \%$ 和 $0.22 \%$ ，距居民点距离增加 $1 \mathrm{~m}$, 分布概率分别增加 $0.04 \%$ 和 $0.03 \%$, 草地还受自然因素的影响，气温越低, 降水越丰富, 其分布概率越大; 在微起伏区受自然和人 为因素的共同影响，气温增加 $1{ }^{\circ} \mathrm{C}$, 林地和草地分布概 率增加 $1.67 \%$ 和 $5.01 \%$, 人口密度增加 1 人 $\mathrm{km}^{-2}$, 分布概 率减少 $0.43 \%$ 和 $0.03 \%$, 受人为因素的影响较平坦区有 所减弱; 林地和草地在小起伏区受气温的影响有所增 强，气温增加 $1{ }^{\circ} \mathrm{C}$ ，分布概率分别增加 $12.2 \%$ 和 $6.39 \%$, 而草地的分布概率与降水量变为负相关，其次与距道 路距离存在相关, 但相关性不显著; 在中起伏区, 林地 和草地受自然因素的影响进一步增强，气温增加 $1{ }^{\circ} \mathrm{C}$, 分布概率分别增加 $34.84 \%$ 和 $11.34 \%$, 降水量增加 $1 \mathrm{~mm}$, 林地分布概率增加 $0.62 \%$, 而草地分布概率减少 $0.48 \%$, 其次人口密度对两者也有贡献, 但贡献不大.

对水域和建设用地的分布具有解释能力的因素相
对较少, 且显著性不高. 在平坦区, 主要受人为因素和 降水量的影响, 人口密度越大, 水域分布概率越小, 而 建设用地越多; 距居民点越远, 水域分布概率越大, 但 建设用地分布概率降低; 降水越丰富, 两者的分布概率 均增大. 在微起伏区, 人口密度越大或降水越多, 两者 的分布概率越大.

综上所述, 在低地形起伏区, 人为因素对景观类型 的分布有较强的解释作用, 人为景观占优势; 在高地形 起伏区, 自然因素对景观类型的分布存在较大贡献, 以 自然景观为主; 而在微起伏区, 受自然和人为因子的共 同作用，因此该区景观类型最丰富，多样性高，异质 性强.

由图7和 8 发现, 随地形起伏度增加, 人为因素对林 地和草地的影响逐渐减弱, 并且对林地的影响强于对 草地的影响. 在平坦区，人为干扰对林地和草地的分 布既有正向影响又有负向影响，正向影响的区域极少， 主要分布在最西端陵川境内, 该区域海拔较高, 但地形 起伏度较小, 为生态工程的实施提供了有利条件; 平坦 区人为活动对林地和草地整体上表现为较强的负向影 响，使林地和草地的分布概率比自然状态平均下降了 $41.26 \%$ 和 $7.74 \%$. 在微起伏和小起伏区, 人为干扰对林 地和草地均为负向影响，使分布概率平均下降 $22.06 \%$ 和 $3.77 \% 、 7.36 \%$ 和 $2.68 \%$. 在中起伏区，林地和草地受 人为干扰的影响最弱, 分布概率仅下降 $1.36 \%$ 和 $0.22 \%$.

\section{5 讨论与结论}

\section{1 讨论}

(1) 地形起伏度对景观破碎度的影响分析. 平坦区 的 $\operatorname{PD}\left(3.07\right.$ 个 $\left.\mathrm{km}^{-2}\right)$ 低于小起伏区的 $\operatorname{PD}\left(3.99\right.$ 个 $\left.\mathrm{km}^{-2}\right)$, 而平坦区的CONTAG(60.51\%)高于小起伏区的CON$\operatorname{TAG}(55.08 \%)$ (表2)，表明以人为景观为主的平坦区的 景观破碎度，低于以自然景观为主的地形起伏度较大 地区的景观破碎度．这可能是由于本文使用 $30 \mathrm{~m}$ 分辨 
表 3 不同地形起伏度类别上景观格局与驱动因素之间的Logistic回归结果 ${ }^{\text {a) }}$

\begin{tabular}{|c|c|c|c|c|c|c|c|c|c|}
\hline & 驱动因子 & & 常量 & 气温 $\left({ }^{\circ} \mathrm{C}\right)$ & 降水量(mm) & $\begin{array}{l}\text { 人口密度 } \\
\left(\text { 人 } \mathrm{km}^{-2}\right)\end{array}$ & $\begin{array}{c}\text { 距农村居民 } \\
\text { 点距离(m) }\end{array}$ & $\begin{array}{c}\text { 距主要道路 } \\
\text { 距离(m) }\end{array}$ & ROC值 \\
\hline \multirow{10}{*}{ 平坦 } & \multirow{2}{*}{ 耕地 } & Beta系数 & 1.7764 & - & - & -0.0007 & -0.0001 & -0.0002 & \multirow{2}{*}{0.726} \\
\hline & & $\operatorname{Exp}(B)$ & 5.9088 & - & - & 0.9993 & 0.9999 & 0.9998 & \\
\hline & \multirow{2}{*}{ 林地 } & Beta系数 & -1.6227 & - & - & -0.0083 & 0.0004 & - & \multirow{2}{*}{0.833} \\
\hline & & $\operatorname{Exp}(B)$ & 0.1974 & - & - & 0.9917 & 1.0004 & - & \\
\hline & \multirow{2}{*}{ 草地 } & Beta系数 & -2.4553 & -0.0882 & 0.0032 & -0.0022 & 0.0003 & - & \multirow{2}{*}{0.716} \\
\hline & & $\operatorname{Exp}(B)$ & 0.0858 & 0.9156 & 1.0032 & 0.9978 & 1.0003 & - & \\
\hline & \multirow{2}{*}{ 水域 } & Beta系数 & -3.2982 & - & 0.0007 & -0.0008 & 0.0001 & - & \multirow{2}{*}{0.711} \\
\hline & & $\operatorname{Exp}(B)$ & 0.0369 & - & 1.0007 & 0.9992 & 1.0001 & - & \\
\hline & \multirow{2}{*}{ 建设用地 } & Beta系数 & -2.9593 & - & 0.0016 & 0.0017 & -0.0002 & - & \multirow{2}{*}{0.721} \\
\hline & & $\operatorname{Exp}(B)$ & 0.0519 & - & 1.0016 & 1.0017 & 0.9998 & - & \\
\hline \multirow{10}{*}{ 微起伏 } & \multirow{2}{*}{ 耕地 } & Beta系数 & 1.2366 & - & -0.0025 & 0.0004 & - & - & \multirow{2}{*}{0.732} \\
\hline & & $\operatorname{Exp}(B)$ & 3.4438 & - & 0.9975 & 1.0004 & - & - & \\
\hline & \multirow{2}{*}{ 林地 } & Beta系数 & -2.8390 & 0.0167 & 0.0032 & -0.0043 & - & - & \multirow{2}{*}{0.714} \\
\hline & & $\operatorname{Exp}(B)$ & 0.0585 & 1.0168 & 1.0032 & 0.9957 & - & - & \\
\hline & \multirow{2}{*}{ 草地 } & Beta系数 & -3.8094 & 0.0501 & 0.0043 & -0.0003 & - & - & \multirow{2}{*}{0.727} \\
\hline & & $\operatorname{Exp}(B)$ & 0.0222 & 1.0514 & 1.0043 & 0.9997 & - & - & \\
\hline & \multirow{2}{*}{ 水域 } & Beta系数 & -0.5792 & - & 0.0005 & 0.0020 & - & - & \multirow{2}{*}{0.704} \\
\hline & & $\operatorname{Exp}(B)$ & 0.5603 & - & 1.0005 & 1.0020 & - & - & \\
\hline & \multirow{2}{*}{ 建设用地 } & Beta系数 & -2.7482 & - & 0.0001 & 0.0004 & - & - & \multirow{2}{*}{0.732} \\
\hline & & $\operatorname{Exp}(B)$ & 0.0640 & - & 1.0001 & 1.0004 & - & - & \\
\hline \multirow{6}{*}{ 小起伏 } & \multirow{2}{*}{ 耕地 } & Beta系数 & 0.5692 & -0.0867 & 0.0013 & - & 0.0001 & - & \multirow{2}{*}{0.716} \\
\hline & & $\operatorname{Exp}(B)$ & 1.7668 & 0.9170 & 1.0013 & - & 1.0001 & - & \\
\hline & \multirow{2}{*}{ 林地 } & Beta系数 & -2.0510 & 0.1151 & - & - & - & -0.0001 & \multirow{2}{*}{0.751} \\
\hline & & $\operatorname{Exp}(B)$ & 0.1286 & 1.1220 & - & - & - & 0.9999 & \\
\hline & \multirow{2}{*}{ 草地 } & Beta系数 & -1.1361 & 0.0639 & -0.0013 & - & - & -0.0002 & \multirow{2}{*}{0.754} \\
\hline & & $\operatorname{Exp}(B)$ & 0.3211 & 1.0660 & 0.9987 & - & - & 0.9998 & \\
\hline & 地地 & Beta系数 & -0.6458 & 0.2989 & 0.0062 & -0.0002 & - & - & 076 \\
\hline 中 & 不地 & $\operatorname{Exp}(B)$ & 0.5242 & 1.3484 & 1.0062 & 0.9998 & - & - & 0.100 \\
\hline & 莫地 & Beta系数 & -1.0262 & 0.1074 & -0.0048 & -0.0001 & - & - & 0 750 \\
\hline & & $\operatorname{Exp}(B)$ & 0.3584 & 1.1134 & 0.9952 & 0.9999 & - & - & 0.150 \\
\hline
\end{tabular}

a) -表示未通过 0.05 显著性检验; Beta系数为回归系数, $\operatorname{Exp}(\mathrm{B})$ 为发生比率, 衡量驱动因子对景观格局的影响程度

率的数据, 导致作为廊道的道路与河流对景观格局的 切割作用没有体现出来. 有研究表明破碎度对于粒度 变化最敏感(高江波和蔡运龙, 2010), 而小尺度区域景 观破碎度的分析对粒度的要求更高(江东等, 2016). 未 来的研究应该使用更高分辨率的影像, 并结合实地调 查以提高数据精度, 从而探究小尺度区域地形起伏度 与景观格局指数特别是与破碎度的相关关系的粒度
效应.

（2）地形起伏度对景观格局的影响机理分析. 以上 4.3 节的讨论表明，在不同地形起伏度类别上，自然和 人为因素的组合状况是景观格局形成的决定性因素. 由图9可见, 随地形起伏度增加, 自然因素中气温逐渐 降低, 降水量逐渐增多, 人为因素中人口密度逐渐减 小, 距道路和居民点的距离逐渐增大. 在平坦和中起 

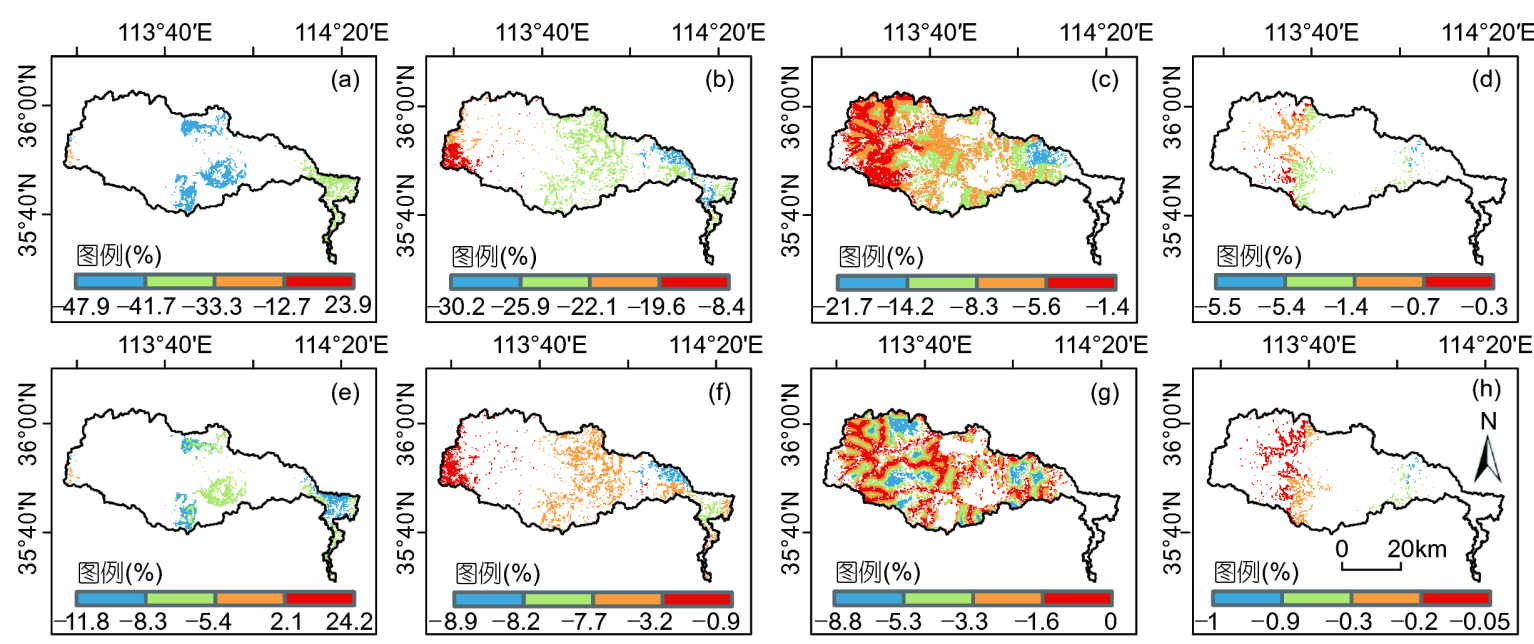

图 7 不同地形起伏度类别上林地和草地实际与潜在分布概率差值的空间分布

(a) (d) 平坦、微起伏、小起伏及中起伏区的林地实际与潜在分布概率之差; (e) (h) 平坦、微起伏、小起伏及中起伏区的草地实际与潜在分 布概率之差

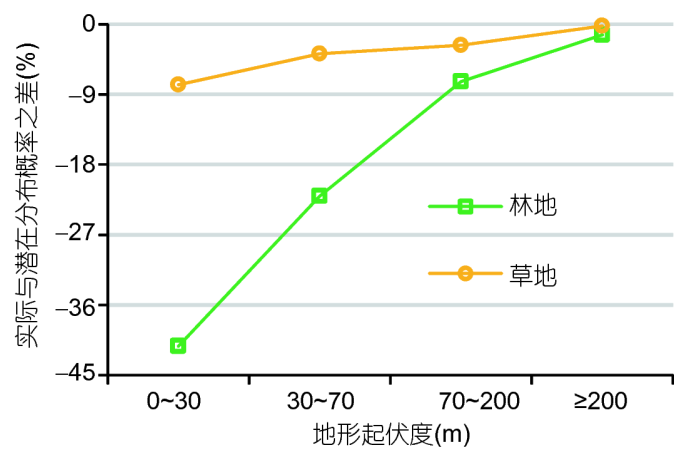

图 8 实际与潜在分布概率的平均差值随地形起伏度的 变化

伏区, 自然和人为因素的组合条件较差, 人为景观和自 然景观分别占据优势, 因此类型单一, 多样性和破碎度 较低, 聚集度和蔓延度较大. 在微起伏和小起伏区水热 条件适宜, 人口密度和可达性适中, 其中微起伏区自然 和人为因素组合条件最佳，景观类型受自然和人为活 动的共同影响，自然景观与人为景观交错分布，类型 丰富, 多样性高, 同时破碎度也达到最高, 说明适当的 人为干扰有利于增强景观多样性，但同时加剧了景观 破碎度.

本研究利用Logistic回归模型不仅对景观格局形 成的具体影响因素进行了系统的定量分析，并利用景 观类型实际与潜在分布概率的差值估算了人为干扰的 综合影响. 相比以往研究所采用的定性方法及相关分
析方法等(肖翠等，2014; 刘吉平等，2016)更具有解释 能力和说服力; 与Jaimes等(2010)和荣子容等(2012)分 别使用的地理加权回归和Logistic回归仅定量分析了 各人为因子的作用相比，本文突出了对人为干扰的综 合作用的探究. 本文的思路和方法更有助于认识自然 和人为活动在景观格局形成和变化中的相对作用，而 且对于自然和人为干扰对生态过程影响的定量研究具 有重要的借鉴意义.

此外，流域尺度土壤性质和水文过程等也会引起 景观格局的变化, 未来的研究应该以系统论为指导, 全面分析由地形分异引起的气候、土壤、水文以及人 为干扰程度等的差异对景观格局的影响，并考虑各影 响因素之间的协同效应，进一步明确不同地形特征下 流域景观格局的主控因素，从而更准确地认识地形对 景观格局的影响机理.

\section{2 结论}

太行山淇河流域位于山地平原过渡带，随着地形 的变化，土壤、植被、气候(气温和降水)等自然地理 要素发生了明显变化, 形成了山地垂直带谱, 从而构 建了流域的特殊景观格局. 本文运用景观生态学原理, 采用相关分析和Logistic回归分析，不仅揭示了地形起 伏度与景观格局的直接关系，而且探讨了两者关系的 机理. 结论如下:

（1）淇河流域地形以小起伏(70 200m)为主, 主要 

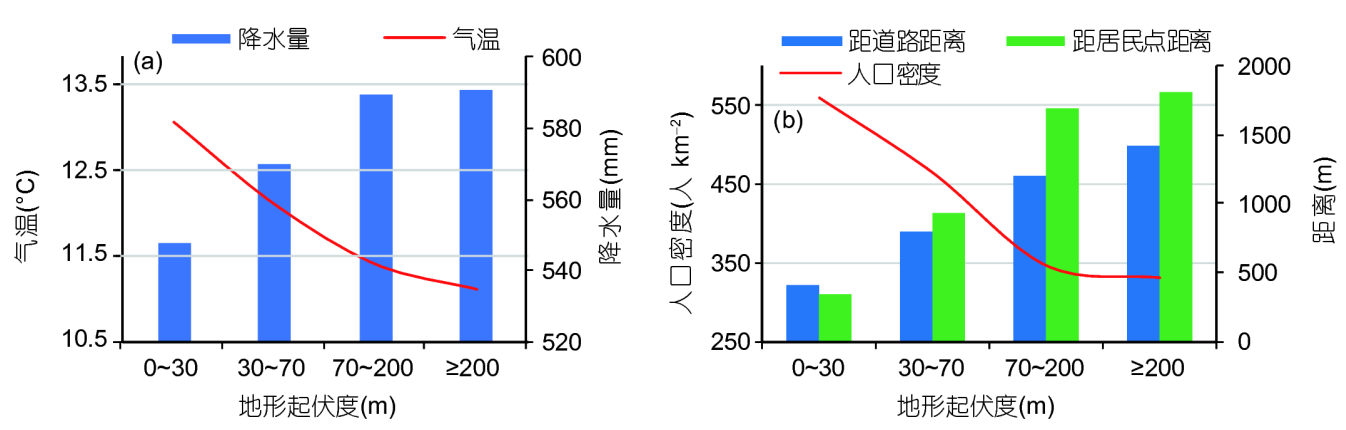

图 9 自然(a)和人为(b)因素随地形起伏度的变化

位于淇河中上游; 其次为平坦 $(0 \sim 30 \mathrm{~m})$ 及微起伏 (30 70m), 位于研究区两端及中部林州境内; 中起伏 $(\geq 200 \mathrm{~m})$ 占比例较少，位于河南与山西及林州与鹤壁 的交界处.

(2) 随地形起伏度增加, 景观类型由人为景观逐渐 向自然景观过渡, 景观多样性和破碎度先增后减, 蔓延 度和聚集度先减后增. 在微起伏区多样性和均匀度达 到最大, 破碎化最严重, 连通性和聚集度最差. 而小起 伏区景观多样性略有降低，但破碎度和连通性有所改 善, 受干扰程度相对减少, 生物多样性水平高, 应该是 今后生态保护的关键区. 通过地形对景观格局的影响 研究，可以丰富保护关键区的理论研究，同时对该区 开展有效保护区的建立具有指导意义

(3) 随地形起伏度增加, 自然和人为因子的组合条 件不断发生变化, 在微起伏区组合条件达到最佳. 在低 地形起伏区，人为因子对景观类型的分布有较强的解 释作用; 在高地形起伏区，自然因素对景观类型的分 布存在较大贡献. 随地形起伏度增加, 人为干扰的综 合影响逐渐减弱, 在平坦区人为干扰使林地和草地分 布概率比自然状态下分别减少 $41.26 \%$ 和 $7.74 \%$, 而在 中起伏区两者的分布概率仅减少 $1.36 \%$ 和 $0.22 \%$.

\section{参考文献}

程国栋, 李新. 2015. 流域科学及其集成研究方法. 中国科学: 地球科 学, 45: 811-819

邓慧平, 孙菽芬. 2012. 地形指数模型TOPMODEL与陆面模式SSiB 的耦合及在流域尺度上的数值模拟. 中国科学：地球科学， 42 : 1083-1093

范建容, 张子瑜, 李立华. 2015. 四川省山地类型界定与山区类型划 分. 地理研究, 34: 65-73

高江波, 蔡运龙. 2010. 区域景观破碎化的多尺度空间变异研究-
以贵州省乌江流域为例. 地理科学, 30: 742-747

管华. 2006. 秦岭-黄淮平原交界带自然地理边际效应. 北京: 科学出 版社. 13-14

国巧真, 宁晓平, 王志恒, 蒋卫国. 2015. 地形地貌对半山区土地利用 动态变化影响分析一以天津市蓟县为例. 国土资源遥感，27: 153-159

哈凯, 丁庆龙, 门明新, 许䶐. 2015. 山地丘陵区土地利用分布及其与 地形因子关系——河北省怀来县为例. 地理研究, 34: 909-921

江东, 阎晓曦, 付晶莹. 2016. 人类活动信息多尺度遥感影像提取的 适用性比较——灵武白菆滩自然保护区为例. 资源科学, 38 : $1409-1422$

广生舜. 1991. 河南山地植被的垂直分布规律. 河南师范大学学报(自 然科学版), 19: 91-95

刘吉平, 董春月, 盛连喜, 刘雁. 2016. 1955 2010年小三江平原沼泽 湿地景观格局变化及其对人为干扰的响应. 地理科学, 36: 879887

刘纪远. 1997. 国家资源环境遥感宏观调查与动态监测研究. 遥感学 报, 1: 225-230

荣子容, 马安青, 王志凯, 周凯. 2012. 基于Logistic的辽河口湿地景观 格局变化驱动力分析. 环境科学与技术, 35: 198-203

茹文明. 1993. 太行山南段植被的研究. 山西师范大学学报(自然科学 版), 7(增刊): 54-58

邬建国. 2007. 景观生态学: 格局、过程、尺度与等级. 第2版. 北京: 高等教育出版社. 106-115

肖翠, 解雪峰, 吴涛, 蒋国俊, 边华菁, 徐伟. 2014. 浙江西门岛湿地景 观格局与人为干扰度动态变化. 应用生态学报, 25: 3255-3262

张春英, 张春玲. 2012. 植被景观指数随复合地形因子分异的变化规 律. 中国农学通报, 28: 65-68

赵卫权, 苏维词, 袁俊. 2010. 基于地形起伏度的贵州省景观空间格 局分异特征. 水土保持研究, 17: 105-110

周成虎, 程维明, 钱金凯, 李炳元, 张百平. 2009. 中国陆地 $1: 100$ 万数 字地貌分类体系研究. 地球信息科学学报, 11: 707-724

Achmad A, Hasyim S, Dahlan B, Aulia D N. 2015. Modeling of urban growth in tsunami-prone city using logistic regression: Analysis of 
Banda Aceh, Indonesia. Appl Geogr, 62: 237-246

Dorner B, Lertzman K, Fall J. 2002. Landscape pattern in topographically complex landscapes: Issues and techniques for analysis. Landsc Ecol, 17: 729-743

Hais M, Chytrý M, Horsák M. 2016. Exposure-related forest-steppe: A diverse landscape type determined by topography and climate. J Arid Environ, 135: 75-84

Hoechstetter S, Walz U, Dang L H, Thinh N X. 2008. Effects of topography and surface roughness in analyses of landscape structure. Landsc Online, 3: 1-14

Jaimes N B P, Bosque Sendra J, Gómez Delgado M, Franco Plata R. 2010. Exploring the driving forces behind deforestation in the state of Mexico (Mexico) using geographically weighted regression. Appl Geogr, 30: 576-591

Li H B, Wu J G. 2004. Use and misuse of landscape indices. Landsc Ecol, 19: 389-399

Lippok D, Schleuning M. 2013. Topography and edge effects are more important than elevation as drivers of vegetation patterns in a neotropical montane forest. J Veg Sci, 25: 724-733

Odgaard M V, Bøcher P K, Dalgaard T, Moeslund J E, Svenning J C. 2014. Human-driven topographic effects on the distribution of forest in a flat, lowland agricultural region. J Geogr Sci, 24: 76-92

Pe'er G, Heinz S K, Frank K. 2006. Connectivity in heterogeneous landscapes: Analyzing the effect of topography. Landsc Ecol, 21: $47-61$

Pekin B K. 2016. Anthropogenic and topographic correlates of natural vegetation cover within agricultural landscape mosaics in Turkey. Land Use Policy, 54: 313-320

Pontius Jr R G, Schneider L C. 2001. Land-cover change model validation by an ROC method for the Ipswich watershed, Massachusetts, USA. Agric Ecosyst Environ, 85: 239-248

Prima O D A, Echigo A, Yokoyama R, Yoshida T. 2006. Supervised landform classification of Northeast Honshu from DEM-derived thematic maps. Geomorphology, 78: 373-386

Walz U, Hoechstetter S, Drăguţ L, Blaschke T. 2016. Integrating time and the third spatial dimension in landscape structure analysis. Landsc Res, 41: 279-293

Yu H, Luo Y, Liu S Q, Yang Y, Liu W D. 2015. The influences of topographic relief on spatial distribution of mountain settlements in Three Gorges Area. Environ Earth Sci, 74: 4335-4344

Zhang B P, Yao Y H. 2016. Implications of mass elevation effect for the altitudinal patterns of global ecology. J Geogr Sci, 26: 871-877

(责任编委: 陈利顶) 